\title{
Small islands, valuable insights: systems of customary resource use and resilience to climate change in the Pacific
}

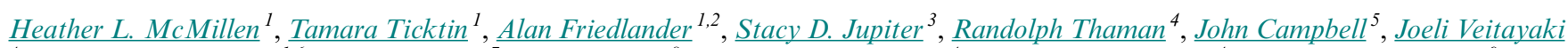
${ }^{4}$, Thomas Giambelluca $^{1,6}, \underline{\text { Salesa Nihmei }}^{7}, \underline{\text { Etika Rupeni }}^{8}$, Lucille Apis-Overhoff $^{4}$, William Aalbersberg ${ }^{4}$ and $^{\text {Dan F. Orcherton }}{ }^{9}$

\begin{abstract}
Understanding how social-ecological systems are and can be resilient to climate change is one of the world's most crucial problems today. It requires knowledge at local and global scales, the integration of natural and social sciences, and a focus on biocultural diversity. Small Pacific Islands and the knowledge-practice-belief systems of their peoples have a long history of resilience to environmental variability and unpredictability, including in areas with marginal habitats and with periodic, severe disturbance (e.g., drought, flood, storms, and tsunami). We review the state of research on these knowledge systems as it pertains to resilience and adaptation, and we highlight critical research needs to address the interrelated areas of: (1) local-scale expertise and observations of change with regard to weather, life-history cycles, and ecological processes; (2) customary resource management institutions and practices (i.e., with agroforests and the nearshore marine environment); and (3) the roles of leaders, social institutions, and social networks in the context of disturbance and change. We conclude that these knowledge systems can contribute high-resolution observations, benchmark data, and insights into practices that enhance resilience and adaptive capacity in integrated terrestrial and marine systems. Community-based and participatory approaches can complement and ground-truth climate models and direct culturally appropriate resource management, research, and adaptation measures. Although most islands in the Pacific are small, their knowledge systems include valuable insights on seasonal cycles, ecological processes, and the management of biocultural diversity that are relevant at a broad scale for understanding resilience and adaptability to the social-ecological effects of climate change.
\end{abstract}

Key Words: biocultural diversity; climate; customary; indigenous andlocal ecological knowledge; Pacific Islands; social-ecological resilience

\section{INTRODUCTION}

Human and natural systems are interlinked in complex ways (Liu et al. 2007a,b, JSSA 2010). Understanding the characteristics of social-ecological systems that confer resilience to climate and environmental change has been identified as one of the world's most pressing problems (Gunderson and Holling 2002, Adger et al. 2005). It requires knowledge from local to global scales (Chaudhary and Bawa 2011, Lauer et al. 2012), the integration of natural and social sciences (Liu et al. 2007b, Barnes et al. 2013), and comprehension of the indigenous and local knowledge (ILK) systems that underpin resilience across space and time (Thaman et al. 2013). Here, we suggest that understanding the role of ILK in the small islands of the Pacific is critical to understanding resilience and adaptation, not only because the islands are extremely exposed to the forecasted effects of climate change (FAO 2010, Keener et al. 2012), but more importantly, because of their long history of resilience to environmental variability (Thaman et al. 2002, Campbell 2009, Barnett and Campbell 2010). Building synergies between ILK and the best cutting-edge science are also seen as a priority under the recently established Intergovernmental Platform on Biodiversity and Ecosystem Services, which is tasked with making global, regional, and subregional assessments as a basis for informing policy and building capacity (Thaman et al. 2013).

In the Pacific, projected increases in sea level, sea surface and air temperatures, and ocean acidification; increasing vulnerability to extreme events (Thaman et al. 2013); and decreases in fresh water supplies and in precipitation in some regions are predicted to have major negative effects on food and water security, biodiversity
(Keener et al.2012), and human health (Patzet al. 2005). Projected rates of climate change, including for the tropical Pacific, are high in relation to natural variability, with negative implications for biodiversity and human welfare, especially for small developing countries with limited financial resources for large-scale adaptation (Mora et al. 2013). The exceptionally high endemism of small islands in the Pacific make the threats to biodiversity especially severe, not just locally, but from a global perspective (Kingsford and Jupiter 2014). For example, $90 \%$ of the indigenous Hawaiian (Wagner et al. 1999) and 62\% of the Fijian (Smith 1996) flora are endemic, and both have exceptionally high numbers of threatened or endangered species, largely due to invasive species and habitat destruction (IUCN 2013). Climate change is predicted to threaten the viability of some narrowly distributed endemics (Price 2009, Krushelnycky et al. 2013) and potentially accelerate the expansion of invasive species (Vorcino et al. 2014).

More significant than their exposure is the resilience of Pacific Islanders. The practices and knowledge associated with their resilience to environmental variability and unpredictability in the past suggest an adaptive capacity that is relevant to addressing the social-ecological effects of climate change now and in the future. Because of local limitations on resources and tight feedback loops, small island communities often see the limitations of their environment more readily, more quickly understand how anthropogenic and natural influences affect resource availability, and adapt accordingly (Poepoe et al. 2007, Berkes 2012, Nakashima et al. 2012). Over several thousand years, Pacific Islanders developed knowledge systems that enabled extensive voyaging, the initial settlement, and continuous habitation of

\footnotetext{
${ }^{1}$ University of Hawai'i at Mānoa, ${ }^{2}$ National Geographic Society-Pristine Seas Project, ${ }^{3}$ Wildlife Conservation Society Fiji Country Program, ${ }^{4}$ University of the South Pacific, ${ }^{5}$ University of Waikato, ${ }^{6}$ Nagoya University, ${ }^{7}$ SPREP, ${ }^{8}$ IUCN/Locally Managed Marine Network, ${ }^{9}$ Centre for Sustainable Technology and Development, Fiji National University
} 
islands across a range of climatic and biogeographic variables. This included developing adaptive responses to living in marginal habitats for food production (e.g., polycutural cultivation, aquaculture, food preservation, consumption of semi-wild foods), with periodic and severe disturbance from drought, cyclones, tsunamis, and volcanoes (Thaman et al. 2002, Nunn 2009, Barnett and Campbell 2010). Because of the high degree of remoteness and the need to be self-sufficient (not necessarily within each individual island, but among islands), the knowledge systems of Pacific Islanders are deeply rooted and complex. Compared to other small islands throughout the world, knowledge systems in the Pacific Islands are well documented, remain widely in practice (e.g., traditional calendars that guide resource use and management), and stand out in their potential to improve our understanding of resilience to anthropogenic climate and environmental changes.

ILK, also known as traditional ecological knowledge (Berkes 2012), comprises customary knowledge-practice-belief systems about the relationships of living beings (including humans) with one another and their environment, emerging through adaptive processes and culturally transmitted over generations. These systems can be conceptualized as four nested levels of analysis: (1) local knowledge of the environment (at the core), (2) associated customary resource management systems, (3) social institutions that guide management practices, and (4) worldviews (which encompass all other levels; Berkes 1999, Fig. 1). Because ILK is dynamic, it often integrates cosmopolitan and scientific information with place-based, experiential knowledge.

Fig. 1. Potential contributions of indigenous and local knowledge systems to social-ecological resilience to climate change. The concentric circle represents indigenous and local knowledge systems from knowledge to worldviews (adapted from Berkes 1999). The external circles identify ways local ecological knowledge systems can contribute to resilience in the context of climate change.

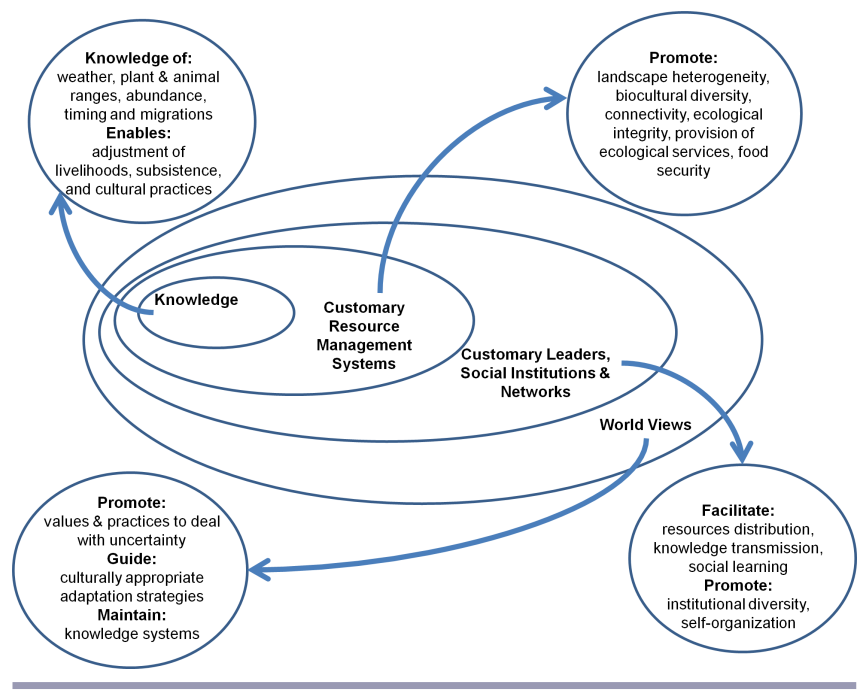

Because of the inherent links within social-ecological systems and among biological and cultural diversity, large-scale biodiversity conservation must also incorporate the cultural-linguistic diversity (Gorenflo et al. 2012) and associated knowledge- practice-belief systems in those areas (e.g., Orcherton 2011, Barthel et al. 2013). A key component of biocultural diversity is the ILK. The localized and temporal depth of understanding in ILK systems is the basis for abundant and growing literature that clearly demonstrates the links between ILK and sustainable resource use (e.g., Bird et al. 2012, Cinner et al. 2012, Schmidt and Ticktin 2012), including in Pacific Islands (e.g., Johannes 2002, Thaman 2008, Friedlander et al. 2013). In the Pacific Islands, ILK systems have also been shown to build adaptive capacity to social and environmental change (Campbell 2006, Barnett and Campbell 2010, Lauer et al. 2012) and to improve understanding of the social-ecological effects of climate change (e.g., Berkes 2009, Lauer et al. 2012, Rudiak-Gould 2014). Scholarship on disaster risk management (e.g., Thaman 2002 , McAdoo et al. 2009, Mercer 2010) has led the way for research on the role of ILK in strengthening resilience to climate change, and this research continues to develop in the Pacific (Green et al. 2010, Lefale 2010, Alexander et al. 2011).

Here, our interest in Pacific Islands spans from Papua New Guinea in the West to Easter Island in the East (including Australia and New Zealand, but with a focus on small islands). This vast expanse has been conceived of in a number of ways, including: regionally, as Polynesia, Micronesia, and Melanesia; geographically, as high and low islands; and linguistically, with an astounding diversity represented by approximately $20 \%$ of the world's 7106 living languages (Lewis et al. 2014). Although the variation across the region is well-established, there are also commonalities that enable and are cause for the circulation and movement of people, ideas, and material and nonmaterial goods within the region. The eminent scholar, the late Epeli Hau'ofa, emphasized how the "universe" of people in the Pacific Ocean has not been confined to land surfaces but is based on the expansive sea that surrounds and connects them (Hau'ofa 1994:152). He characterized the region as a "sea of islands", rather than existing as individual "islands in a far sea" (Hau'ofa 1994:153). This important distinction explains how we can consider the customary knowledge-practice-belief systems of such an expansive area in our discussion here, and how it is distinct from ILK in other regions of the world.

While ILK is place based and noted for its fine spatial scale, the connections among Pacific Islands and the movement of people (in terms of ancient migrations, interactions through trading and cultural exchange systems, and in modern contexts with Pacific Islanders living in diaspora) mean that some aspects of ILK are regional (though not uniform). For example, Pacific Islander ILK systems typically feature knowledge and practices related to cultivation of a range of species (e.g., taro, swamp taro, bananas, breadfruit, yam, sweet potato, coconut, pandanus, and more recently, cassava). The consumption of kava unites many parts of the region, both in ritual as well as in mundane settings. In the marine context, detailed knowledge and management of fishponds (Costa-Pierce 2002), fish weirs and traps (Dieudonne et al. 2002), gleaning (Chapman 1987), and nearshore and open ocean fishing (Johannes 1981, 2002, Hviding 1996, Ruddle 1998) are also characteristic. Important features of these systems include traditionally placed restrictions on specific species, lifeforms, people, places, or times, with "the tabu areas of Fiji, Vanuatu and Kiribati, the ra'ui in the Cook Islands, the kapu in 
Hawai 1 , the tambu in PNG [Papua New Guinea], the bul in Palau, the mo in the Marshall Islands, the tapu in Tonga and the rahui in New Zealand (Māori)" (Vierros et al. 2010:7). Also central, if not paramount, among Pacific Islander ILK systems and identities are the traditions of seafaring and voyaging. The practices of open ocean wayfinding co-evolved with knowledge systems that include a profound understanding of ocean swells, wind, and meteorological, celestial, and biological cycles, upon which safe travel and accurate landings are determined (Lewis 1994). Another distinguishing feature of ILK systems in the region, especially on small islands, is the recognition of the interconnections across systems (e.g., terrestrial-riparian-marine, social-ecological). These "ridge to reef" concepts are reflected in land tenure and management practices that demonstrate an understanding of connections between upstream and downstream activities. This concept has been fundamental to ILK in Hawai'i (Blaisdell et al. 2005), Palau (Golbuu et al. 2011), Fiji and the Solomon Islands (Ruddle and Akimichi 1984, Baines 1989), and elsewhere.

Lessons from Pacific Islands might teach us about future adaptation and resilience on small islands, with broader implications globally (Fig. 1). There is a great need for better understanding of Pacific Island climate change adaptation and resilience, which has been emphasized by those in research (Mercer et al. 2007, Thaman 2008, 2009, Duffy 2011) and in policy (UNFCCC 2007, FAO 2010, Keener et al. 2012). Our objective is to present a review of and research vision for investigating the role of ILK in enhancing resilience to the effects of climate and environmental change in Pacific Islands, a vision that brings to the foreground the importance of place-based approaches and the need to support and empower local knowledge systems for climate change adaptation planning. To do this, we apply a socialecological resilience framework (Gunderson and Holling 2002), which acknowledges that coupled human-natural systems are intrinsically dynamic (Nelson et al. 2007). Resilience is "the capacity to absorb shocks and maintain function, self-organize and learn and adapt" (Carpenter and Brock 2008), and resilience to disturbance requires institutional capacity to respond to environmental feedback, to learn and store information, and to be prepared to adapt to change (Holling 2001). Adaptability is a social component that refers to "the capacity of actors in the system to influence resilience"(Walker et al. 2004), and it is shaped by the resilience of both its social institutions and the natural ecosystems on which they rely (Folke et al. 2003).

Here, we review the state of knowledge of ILK as it pertains to resilience and adaptation. This is based on searches of the peerreviewed literature across the natural and social sciences (e.g., primarily through Google Scholar, Biological Abstracts, and Social Sciences Citation Index), ethnographic literature, gray literature, and project websites (including government, nongovernment, and nonprofit). The primary literature review was conducted from December 2012 through April 2013 (with subsequent reviews to update findings). Focal areas of the research emerged from a 2012 workshop on ILK and climate change (held in Suva, Fiji), with regional experts participating. Search keywords included: islands, climate change, disaster management, indigenous knowledge, indigenous ecological knowledge, traditional knowledge, traditional ecological knowledge, resilience, adaptive capacity, adaptation, nutrition, local knowledge, indigenous knowledge, traditional knowledge, local ecological knowledge, agroforesty, marine, communitybased resource management, and resource management. Here, we focus on Pacific Islands and highlight critical research needs to address the interrelated areas of: (1) local-scale expertise and observations of change with regard to weather, life history cycles, and ecological processes; (2) customary resource management institutions and practices; and (3) the roles of local leaders, social institutions, and social networks in the context of disturbance (Box 1).

\section{RESULTS AND DISCUSSION}

\section{Observations of weather, life history cycles, and ecological processes}

In the Pacific Islands, global climate model projections are challenged by the islands' small-scale topographic features, the strong influences of El Niño/Southern Oscillation and the Pacific Decadal Oscillation (Timm and Diaz 2009), and the dearth of "long-term, high-quality data on rainfall, stream flows, waves, and [the functioning of] ecosystems" (Keener et al. 2012:120). ILK that distinguishes and communicates past patterns in atmospheric phenomena, weather, phenology, and ecological processes enables people to anticipate and prepare for future conditions (Orlove 2003, Acharya 2011). Understanding and adapting to environmental change has been the basis for the evolution of human subsistence and for directing communal activities across time and space, such as where and when to fish, plant, harvest, conserve, feast, voyage, relocate, migrate, etc. (e.g., Green et al. 2010, Lefale 2010, Leonard et al. 2013). The ILK of Pacific Islanders includes a rich understanding of atmospheric, weather, and seasonal cycles based on long-term observations, which they draw upon to identify and evaluate the effects of a changing climate (Green et al. 2010, Leonard et al. 2013). We propose three research priorities for learning from Pacific Islander ILK to deepen our understanding of climate change.

Box 1. Recommended priorities for research on ILK and resilience to climate change in Pacific Islands.

- Conduct site-specific seasonal calendar studies across and within islands to set reference points for identifying current and future change and for communicating between local and scientific observers;

- Coordinate with and integrate climate change monitoring into successful community-based natural resource monitoring programs;

- Use ILK-informed observations as the basis for formulating research questions and hypotheses to guide research on environmental and climate change;

- Record, monitor, and share local observations and experimentation (i.e., which crops respond or endure best under climatic stress, how migrations and phenology are changing) so they can be compared across locations and inform an understanding at a regional level;

- Work with traditionally trained navigators and document their knowledge of typical conditions and patterns as well 
as observations of change with regard to ocean conditions, weather, and migrations of birds and marine mammals;

- Explore and identify how customary resource management practices (e.g., agroforestry and nearshore fishing) are adapting to changing conditions (climatic, socioeconomic, and ecological) and assess impacts on indicators of resilience;

- Explore the ability of agroforests to moderate extremes in water flow, their ecological benefits to adjacent forest areas, and how this affects resilience;

- Explore the effects of drought, storms/floods, saltwater incursion, and inundation on different crop varieties and species in agroforestry systems;

- Assess how customary fisheries management practices might affect ecological resilience under various climate change scenarios;

- Identify if/how customary agroforestry and other agricultural practices might be expanded and adapted to help address the effects of the predicted decline in coastal fisheries;

- Explore the dynamics among leadership roles (i.e., customary, church, government, and nonprofit leaders), institutional diversity, local communities, and resilience to climate change;

- Explore how integrated, culturally appropriate adaptation strategies that include ILK and build upon customary governance structures can best be implemented and disseminated;

- Explore how adaptation measures can foster effective resource management and social resilience by incorporating ILK and involving women, youth, and nonindigenous community members;

- Explore and document current practices of reciprocity and social network exchanges in different economic and market contexts;

- Explore how to integrate cultural values and practices that promote resilience into adaptation communication and planning.

\section{Seasonal calendars}

People define time based on astronomical (movement of stars, sun, moon), meteorological (wind, weather), and cultural (human activities) elements (Malinowski 1927). Segments of time are often structured around the concept of seasons, which are recognized and named by people around the world (Orlove 2003). In Melanesia, Mondragón (2004:289) explains, "local groups often create associations between the patterns and perturbations of the environment and cycles of human production which constitute organizing frameworks evocative of what Western observers label 'calendars'." Here, we use the term "calendar" to refer to such a spatio-temporal concept, whether it is intangible and has been passed down through oral tradition, a tangible calendric representation in the Western sense, or something between the two.

Over millennia, indigenous people in the Pacific Islands and Australia have developed customary calendars that include expectations of weather (e.g., wet and dry seasons), phenological characteristics (e.g., the fruiting of Pandanus spp. and breadfruit [Artocarpus altilis], or the rising and spawning of the palolo sea worm [Eunice viridis]), as well as the astronomical cycles that characterize the seasons or correlate with weather conditions and establish the timing of resource management, horticultural, and ritual events (e.g., final feast, first digging of yams; Mondragón 2004, Green et al. 2010, Lefale 2010, Leonard et al. 2013).

Building on the foundation of early anthropologists in the Pacific Islands who described indigenous concepts of time (e.g., Malinowski 1922, Leach 1950), noteworthy research describing the characterizations of seasons has followed from ancient (e.g., Kirch and Green 2001) to contemporary populations (e.g., Sillitoe 1994, Mondragón 2004). These concepts are generally structured as lunar calendars that direct fishing and horticultural activities based on expectations of precipitation. Despite the foundation of scholarship in this area and the rich systems of ILK in the Pacific, the significance of customary seasonal calendars to understanding social-ecological effects of climate change has only been described in a handful of cases, with a large representation from Aboriginal Australians, including the Miriwoong people from East Kimberly (Leonard et al. 2013), Walpiri from central Australia, Martu from northwestern Australia, and others (Prober et al. 2011), and Torres Strait Islanders (Green et al. 2010). We are aware of only two published studies with Pacific Islanders: Te Whānau-ā-Apanui, a Māori tribal group in Aotearoa (King et al. 2008) and Samoans (Lefale 2010), and an in-progress project in Ka ūpūlehu, Hawai i. Although research on the topic is still emergent, the value of seasonal calendars is realized in the applied world. For example, the Micronesia Conservation Trust (a nongovernmental organization) engages a community-based process in Micronesia to document seasonal calendars and observations of change as a strategy for understanding and facilitating adaptation to the social and biological effects of climate change (Gombos et al. 2013). UNESCO supports efforts to inform climate change policies through promoting the indigenous voices behind seasonal calendars and the local environmental knowledge, values, and practices they embody (e.g., http://www.unesco.org/new/en/apia/ natural-sciences/local-indigenous-knowledge/traditional-knowledgecalendars/). Because seasonal calendars focus on past patterns in annual variability, they represent an opportunity to identify current and future changes by serving as reference points, especially in cases where information is not well documented in the scientific literature (e.g., Thornton and Scheer 2012). In addition to being valuable tools for communicating nuanced, place-based information to scientists, calendars are also valuable for supporting the transmission of ILK from elders to the next generation, thereby providing a resource for adapting to changing conditions (Leonard et al. 2013) and strengthening resilience (van Oudenhoven et al. 2011; Box 1).

Because seasonal phenomena can vary within islands (e.g., windward and leeward sides) and because pressure on resources varies across islands, conducting site-specific seasonal calendar studies is a research priority (Box 1). Different levels of human 
population growth and pressure on resources is reflected in variation in existing customary calendars. Some calendars focus on conservation and management (e.g., marine resource management in Hawai i). Others have more emphasis on optimal harvest and yield, such as those in Fiji, where large-scale resource pressure is relatively new, and therefore, is not represented strongly in customary seasonal or moon calendars that guide the use and management of marine resources. This range of conditions and responses suggests the need for research to investigate how variation in calendars relates to managing for resilience today. In cases when representations of calendars are not widely known, or conditions have changed, collaborative and community-based approaches should be used to research and represent ILK about annual cycles appropriately across time and space. For example, in recent years, by observing spawning behavior and fish gonad development, communities in Hawai i have developed calendars identifying the spawning periods for the major resource species (e.g., moi or Pacific threadfin [Polydactylus sexfilis]), which support the establishment of customary seasonal kapu (closures) to protect spawners (Poepoe et al. 2007, Friedlander et al. 2013). In Fiji, Tuvalu, Tokelau, and other areas of the Pacific, the seasonality and large aggregations of post-larval rabbitfishes (Siganus spp.) are featured in legends and linked closely to the names of the months in traditional calendars ( $R$. Thaman, unpublished data). It will be important to conduct this research with attention to intra-cultural variation, as recent research in the Marshall Islands shows that elders (who have had more time to observe environmental change) were significantly "more likely to report a changed climate, sea level rise, and altered seasons," compared to younger adults (Rudiak-Gould 2014:83).

The ethnoclimatology database (Orlove 2003) includes locations, indicators, and timing of seasons. This offers a template for the collection of essential data that could be compared over time and across space. Examples of the co-creation (i.e., through a participatory process) of tabular (Leonard et al. 2013) and circular (Prober et al. 2011) format calendars that represent socialecological indicators of seasons and include weather, phenology, and cultural activities provide further guidance for the process. A notable example from the Miriwoong in Kununurra, Western Australia, is available at: http://www.mirima.org.au/calendar/ (Mirima Council 2011).

\section{Tracking indigenous and local knowledge-informed observations} of changes

Although many indigenous information systems (oral traditions) in the Pacific Islands have eroded, Bridges and McClatchey (2009:143) note: "traditional and modern record keeping practices are reviving. Having thousands of trained eyes watching and documenting what they see happening, because they are using the land rather than removed from it, should be taken by scientists as an opportunity for environmental monitoring and analysis." Other researchers have recommended integrating ILK-informed observations of change into the development of climate change response strategies (e.g., Berkes and Jolly 2001, Salick and Ross 2009), and using long-term community-based monitoring (Cruikshank 2001, Prober et al. 2011, Berkes 2012) to document unusual changes in seasons. Such community-based monitoring can identify population shifts in plant and animals (i.e., new species appearing or others disappearing), changes in species abundance, and changes in the timing of migrations and phenology (Turner and Clifton 2009, Green et al. 2010, Jacob et al. 2010). It can help ground-truth and refine regional climate models, and it can improve the utility of climate change predictions and the confidence in climate change analyses (Marin 2010), which can inform the management of culturally relevant resources, specific species, and social-ecological processes (Fig. $1)$.

Monitoring informed by ILK (i.e., through participatory research) can be more efficient in management and policy responses than scientific research alone (Danielsen et al. 2010). This has been demonstrated in the Pacific, for example, by the Fiji Locally Managed Marine Area Network, which builds on customary marine tenure and taboo (restrictions) for fishing (FLMMA 2011, Jupiter et al. 2014), and in Mo'omomi Bay (Moloka'i, Hawai'i), where community-based monitoring informed by ILK supports a sustainable fishery (Poepoe et al. 2007). The knowledge, awareness, and motivation needed to make programs like these successful also apply to monitoring climate change. Research on climate change could be more efficient and meaningful if it is coordinated with and integrated into successful community-based monitoring programs that empower local communities by listening to and promoting their ILK (Fig. 1). For instance, a fisheries monitoring program could supplement ILK with additional fields to note shifts in the timing of spawning or migrations, changes in weather patterns, and/or other locally relevant variables. Deciding which variables are most appropriate to monitor needs to be part of a participatory process to ensure they are tailored to place, important to the local community, and make sense in the local language. Concepts such as "resilience" and "climate" do not necessarily have equivalent or direct expressions in local languages (see Grantham et al. 2011 for an example from Fiji). We strongly advocate a commitment to participatory approaches and rigorous ethnographic research to yield accurate and precise data on local observations of change, and to join communities in addressing questions that are significant, e.g., to local food security, water security, health, and cultural identity. In addition, we encourage scientists to look to ILK-informed observations as the basis for formulating research questions and hypotheses to guide research on environmental and climate change (e.g., Bart 2006; Box 1).

Although multiple community-based observation networks that rely on ILK to identify the social-ecological effects of environmental change have been established in the Arctic (e.g., Mahoney et al. 2009, Huntington et al. 2011, Eisner et al. 2012), there is still a need for coordination of observations in the Pacific Islands. There are opportunities to learn from and expand existing programs such as the Vanuatu National Climate Change Adaptation Strategy, which includes a catalog of almost 500 strategies based on customary and local knowledge for dealing with extreme events (e.g., knowledge related to forestry, agriculture, water use, etc., for dealing with cyclone, drought, fire, flooding, and sea level rise; Republic of Vanuatu 2011). By involving farmers, fishers, hunters, gatherers of nontimber forest products and, in the case of Hawai' $i$, ranchers, in research, we can expand the understanding of environmental changes (e.g., species distributions, phenology, landscape, and ecological processes) and how to deal with them, thus providing critical information for making more suitable and timely decisions about resource management (Fig. 1). 
Research on seasonal calendars and ILK-informed observations of change are complementary. Together, they have great potential for better understanding and tracking change and for shaping research that is meaningful to and resonates with local people's on-the-ground experiences, values, and needs. It is critical to frame and scale research with ILK perspectives; otherwise, scientific research risks being "too narrow, shallow, or broad to be meaningful in the context of community adaptation at the landscape scale" (Thornton and Scheer 2012). This kind of monitoring is critical beyond the local scale. Across the Pacific Islands, there is a need for a systematic way of recording, monitoring, and sharing local observations so they can be compared across locations (e.g., which crops respond or endure best in climatic stress, how migrations and phenology are changing; see Box 1). This can inform adaptive management more broadly.

\section{Navigators' knowledge}

In the Pacific Islands, the ancient and ingenious system of noninstrument wayfinding is based on "observations of stars and other heavenly bodies as well as of the changing wind and sea states, the patterning of the clouds, the flight of land-nesting seabirds and other facets of the marine environment" (Finney and Low 2006:156). In the region, traditional navigators recognized the correlation between the rising of specific stars and the timing of storms, using these for reckoning time and planning voyages (e.g., Erdland 1914). Because knowledge of weather is essential for navigators, they are well positioned to make unique and complementary contributions to the understanding of changes in weather patterns, especially conditions in the deep sea, open ocean environment. Although there is a solid foundation of scholarship on traditional navigation (e.g., Lewis 1994, Finney 1998), especially as it concerns the migration routes and settlement of the Pacific Islands (e.g., Finney 1977, Howe 2006), navigators' knowledge and observations of climate change remain largely unexplored. Although such knowledge declined in the first half of the twentieth century, there has been a resurgence of traditional voyaging and the use of traditional navigation systems in the Pacific Islands (Finney 2003, Genz 2011), and much collaboration with and integration of global scientific research and educational programs, especially related to environmental stewardship. (Exemplary is the Hōkūle‘a, a double-hulled voyaging canoe which was first launched in 1975 and fueled the Hawaiian Renaissance. Its worldwide voyage from 2012-2017 is focused on promoting sustainability, as summarized by the slogan "Island Wisdom, Ocean Connections, Global Lessons". See: http://hokulea.org/). Given the high uncertainty in future projections of changes in Pacific Ocean currents (Vecchi et al. 2006) and trade wind patterns (Garza et al. 2012), research with navigators may also offer an opportunity to learn how knowledge systems are adapting to changes in weather and marine organisms. A high priority should be given to working with navigators to document their knowledge of typical conditions and patterns as well as any observations of change with regard to ocean conditions, weather, and migrations of birds and marine mammals (Box 1). An equally high priority should be given to learning from successful education and knowledge transmission efforts around the topics of sustainability and resilience, as they are crucial for climate change adaptation.

\section{Customary resource management systems}

Customary resource management systems are based on ILK and developed through adaptive processes. They rely on the ability of resource users or managers to understand environmental feedbacks and modify practices accordingly (Berkes 2012). Customary resource management systems exist across the globe, usually alongside other kinds of land and sea management. In some places, they are the dominant system, in others, they have become marginal. However, they remain important for subsistence and well-being in many of the regions that are expected to be most affected by climate change such as the arctic (Berkes 2012), mountaintop communities (Salick and Ross 2009), and small island nations.

Customary resource management systems often center on the manipulation of regeneration cycles and ecological processes (Alcorn 1989, Altieri et al. 1989). For example, in shifting agriculture systems, the process of succession is manipulated as ecological communities and landscapes are managed through temporary small-scale clearings and, in many cases, controlled fires. There is growing evidence that some customary resource management systems in the Pacific can play a key role in maintaining ecological integrity in the context of disturbance (Ticktin et al. 2006, Bird et al. 2012, Trauernicht et al. 2013). Customary resource management systems have also been recognized as key to building adaptive capacity in small Pacific Islands (Campbell 2006, Barnett and Campbell 2010, Vaughan and Vitousek 2013), but they continue to be modified under rapidly changing social, economic, and ecological contexts (Cinner and Aswani 2007, Brewer et al. 2012, Lauer et al. 2012).

Many customary resource management systems are based on understanding the interconnectedness of different habitats and members of the ecosystems, including humans. They often involve the combined production of both plants and animals, including fish, and the integrated management of a diversity of vegetational zones that overlap in space and time such as home gardens, agricultural areas or agroforests and fallows of differing ages, and interspersed wild areas, including forests, lakes, grasslands, and swamps (Tuxill and Nabhan 2001). While scientific research has traditionally conceptualized separate terrestrial and marine systems (and to some extent still does, although ecological research is more integrative), customary resource management systems, including those on small Pacific Islands, recognize their interconnectedness. Examples of these ridge-to-reef concepts are the ahupua' $a$ system in Hawai' $i$ (Blaisdell et al. 2005) and the vanua system in Fiji (Baines 1989), where land and sea space exist as a continuum, and people are an integral part of the ecosystem. The Japan Satoyama-Satoumi Assessment is one of the most comprehensive attempts to show how traditional agricultural, village, rural, and human-managed seascapes constitute critical social-ecological production landscapes, something that has also been shown to be true in the Pacific (Thaman, unpublished manuscript). These conceptual models are valuable for framing research on resilience to climate change because of the social and ecological interconnections they recognize.

Agroforestry and social-ecological resilience

Little research has directly linked the customary resource management practices associated with ILK such as agroforests (traditional polycultural systems) to resilience and adaptation to 
climate change (Tscharntke et al. 2011, Mijatović et al. 2013); however, agroforests in Pacific Islands have been documented as model systems for sustainable food production (Thaman 1976, Vergara and Nair 1985, Raynor and Fownes 1991a,b, Thaman and Clarke 1993, Thaman 2008), and food security is an important indicator of resilience. Most Pacific Island agroforests are variations on shifting agriculture and are typified by the integrated use of a diversity of native and introduced fruit and nut trees and understory agricultural crops (predominantly roots), extended fallow periods, and rainfed irrigation (FAO 2010). They range from extensive to intensive, depending on the local population density (Clarke and Thaman 1993), and are often interspersed with other vegetation zones, including fallows of different stages of regrowth and old-growth forests (Thaman 2008).

Pacific Island agroforestry systems may foster resilience though their contributions to biocultural diversity and food security by producing nutritious foods (e.g., Englberger et al. 2003), including noncultivated plants and nondomesticated animals, that add nutrition and diversity to local diets and decrease dependence on imports (Thaman et al. 2002; Thaman, unpublished manuscript). In addition, they have historically included many aspects thought to increase resilience to climate change (Mijatović et al. 2013), including high species diversity and landscape heterogeneity (Raynor and Fownes 1991 $a$, Clarke and Thaman 1993), integrated forest reserves, and the cultivation of crops with life-forms less susceptible to high winds (i.e., taro and yams compared to cassava, a new-world crop). These agroforestry systems have also been responsible for the provision of many of the ecological services afforded by native forests such as: nutrient and water cycling; soil retention and control of coastal erosion; protection from sea spray and salt water incursion; protection from strong winds, storms, and droughts; facilitation of pollination, dispersal, and propagation; and biological pest control (e.g., Tapia-Coral et al. 2005, Thaman 2008, Quintero et al. 2009, Pfund et al. 2011; Fig. $1)$.

In addition to ecological value, agroforests also have significant socio-cultural value. Pacific Islanders use nuts, fruits, leaves, roots, bark, and wood from agroforests in the creation of culturally important items (e.g., foods, medicines, fuel wood, dyes, carvings, and construction materials). Many are shared (e.g., tapa or barkcloth, woven mats) through ceremonial exchange. The wellknown Kula Ring, documented by Malinowski (1922) in the Milne Bay Province of Papua New Guinea, is an example with ritual exchange of gifts made from shells. These exchanges strengthen social networks and help maintain alliances and relationships of reciprocity, which can be called upon in times of need, and thus promote resilience against local challenges to resource access (Thaman 2008).

Pacific Islanders are adapting their agroforestry systems to address changes to the socioeconomic landscape, including intensive population growth, urbanization, tourism, new crop technologies, and growing markets for commercial crops. However, little information is available on how farmers are adapting their ILK and associated management practices, or on the implications of these changes for sustainability and socialecological resilience. We believe this should be a major research priority. Similarly, agroforestry systems are responding to changing climatic patterns, which affect ecological processes such as pollination and water cycling, as well as other changes such as the introduction of invasive species. Understanding if and how customary agroforests can provide some of the most important ecosystem services needed for resilience to climate change is also crucial, and this question has not been assessed (FAO 2010). The ability of agroforests to moderate extremes in water flow and their ecological benefits to adjacent forest areas (e.g., regeneration, prevention of invasive species) are two areas that have not been well studied but may play critical roles in building resilience (Thaman, unpublished manuscript). Research should also explore the effects of drought, storms/floods, saltwater incursion, and inundation on different crop varieties and species in agroforestry systems. We believe it is critically important to explore how people are experimenting or incorporating new varieties and species (Box $1)$.

Nearshore marine fisheries and social-ecological resilience Historically, Pacific Islanders relied heavily on marine resources for nourishment. In some places, the need to avoid food depletion motivated them to develop a sophisticated understanding of the limitations to and fluctuations in marine resources. Through observations, learning, and adaptation over time, certain Pacific Island communities developed ingenious social and cultural controls on fishing that fostered sustainable use of marine resources (Titcomb 1972, Johannes 1978). Some of these fishery management systems were not based on overall catch, but instead focused on identifying specific times and places that fishing could occur so as not to disrupt basic ecological processes that supported important food resources (Poepoe et al. 2007, Friedlander et al. 2013). For example, the traditional system in Hawai i (pre-1800) emphasized social and cultural controls on fishing with a code of conduct and prohibitions (kapu) that were strictly enforced (Titcomb 1972). By allowing fish populations to replenish themselves, and by not interfering with important activities such as spawning, Hawaiian communities were able to maintain productivity and fisheries yield at local scales (Friedlander et al. 2013).

In other areas of the Pacific such as Melanesia, customary marine tenure and fishing taboos may have evolved to manage social relationships, rather than a need to conserve fisheries (Foale et al. 2011). Prior to European colonial intrusions, human population densities were low, and the pressure on coastal and marine resources was also likely low. Most Melanesian taboos followed social cycles such as the custom to close an area to fishing for 100 days following the death of a chief to harvest for funeral rites. This period is insufficient to allow for recovery of fish stocks, but potentially sufficient to increase the catchability of fish for social events to generate prestige or mana (power) for the hosts (Jupiter et al. 2014). Tenure boundaries would have been the logical extension of this practice to safeguard the mechanism for generating this prestige.

There has been a renaissance of customary community-based marine management throughout the Pacific (Veitayaki 1998, Johannes 2002, Lutchman et al. 2005, Govan 2009, Friedlander et al. 2013), and the continued use and rediscovery of these techniques could play an important role in improving the management of marine fisheries in the face of changing climate. For example, under certain circumstances, locally managed 
marine areas that incorporate concepts of customary marine tenure can maintain ecosystem integrity while also providing for sustainable use of marine resources (Johannes 1997, Veitayaki 1997, Jupiter et al. 2014); however, there is variation. In Melanesia and elsewhere, persistent customs of periodic harvesting and temporal impermanence of no-take closures may need to be monitored carefully to achieve sustainability (Jupiter et al. 2012b, Cohen and Foale 2013). Because most locally managed marine areas are not legally registered, community managers often have the flexibility to adapt rules and regulations to resource fluctuations (Jupiter et al. 2014). Thus, they may be more capable than centralized governance systems in responding to the localscale effects of climate change. In addition, because reliance on marine resources often increases after hurricanes and drought, knowledge of how to manage the entire ecosystem effectively (from nearshore to pelagic and freshwater) can strengthen resilience (Thaman et al. 2002, Rasumssen et al. 2009; Fig. 1). Studies in Fiji show that holistic local marine areas management may be by far the best means of building resilience and helping seriously overfished areas and areas affected by extreme weather events (tsunamis, etc.) recover lost biodiversity and resilience (Thaman et al. 2014).

Recent research has focused on identifying the key ecological attributes of nearshore marine ecosystems that support ecological resilience (McClanahan et al. 2012). Reef fish biomass, particularly that of certain trophic groups such as apex predators and herbivores, is an important indicator of the health and resilience of coral reef ecosystems (Friedlander and DeMartini 2002, Mumby et al. 2007, 2013), but as exploitation of these assemblage components reaches critical thresholds, the overall health of reefs and the services they provide for human communities can decline dramatically (Bellwood et al. 2004, Sandin et al. 2008). Reefs under stress can shift rapidly into alternate, algae-dominated states that consequently reduce benefits to human communities (Hughes et al. 2007, Mumby 2009). Other key ecological factors such as reef fish trophic structure, ecological functional redundancy, and life history characters have also been proposed as key metrics that influence ecosystem service flows (Nyström et al. 2008).

Pacific Island fisheries are threatened by multiple anthropogenic factors, including overexploitation (which is expected to increase with rapidly rising human population growth in Pacific Islands), pollution, and erosion from upland habitat destruction, among others. The effects of climate change are expected to amplify these stresses. Specifically, rising sea surface temperatures are predicted to lead to increased coral bleaching and eventual coral death (Maina et al. 2011). Ocean acidification is predicted to inhibit coral reef growth, which will result in habitat loss (Keener et al. 2012) and up to $20 \%$ decline in coastal fisheries by 2050 (Bell et al. 2013).

There is a great need, therefore, to understand how customary fisheries management practices might affect ecological resilience under various climate change scenarios (Box 1). Identifying and supporting local practices that promote resilience and are within local control might have potential for addressing new problems operating across larger scales, such as declines in coral health due to ocean acidification and ocean warming. Some evidence suggests that locally managed marine areas can improve resilience potential by increasing herbivory and therefore reducing harmful coral-algal interactions (Rasher et al. 2012). Yet, this is complex because local factors can affect nearshore marine ecosystems (e.g., overfishing, pollution, sedimentation, and habitat destruction) while various socioeconomic changes can greatly affect management practices. For example, recent research has shown that increases in population growth and market opportunities can have profound effects on customary fisheries practices, leading to increased overexploitation (Cinner and Aswani 2007, Brewer et al. 2012). In addition, because the productivity of nearshore fisheries is expected to decline as human populations increase, communities (on high islands) who once relied heavily on fishing to meet subsistence needs may need to rely more on farming. There is a need to assess the capacity of agricultural systems to make up for the food lost due to reduced fishing productivity (Box 1). This underscores the importance of assessing resilience to climate change in Pacific Islands using a perspective that bridges land and ocean resources. The ahupua' $a$ and vanua concepts and the associated customary resource management practices that span from ridge to reef embody ecosystem-based management and provide an appropriate research framework.

\section{Local leaders, social institutions, and social networks}

\section{Customary and other leadership}

The success of resource management, especially under disaster recovery, depends on strong local leadership, social institutions, and social networks. Similarly, local leaders and institutions are critical for implementing adaptation to the effects of climate change (Agrawal 2010). In many Pacific Island nations, customary leaders continue to play important roles in daily governance and responses to disturbance; however, as political, economic, and environmental circumstances have changed, so have customary leaders' roles. Although chiefs in Fiji continue to have strong social standing and influence responses to activities that threaten the marine environment (i.e., destructive fishing, coral harvesting, and development), some chiefs are seen as uninformed when it comes to the state of fisheries (Veitayaki 1998). Their decreased authority, together with a weakened traditional system of control and more productive modern fishing techniques, challenges marine resource management (Veitayaki 1998).

Traditionally, chiefs throughout Polynesia were responsible for organizing community responses to disasters (Mercer et al. 2007, Colding et al. 2008). Today, other community leaders respond in times of crisis and need as well. For example, both customary leaders and church leaders in the Solomon Islands organize the distribution of food and other assistance following disasters (Rasmussen et al. 2009, Lauer et al. 2012; Fig. 1). The influence of the church in directing resource use and harvest can go beyond disaster response. Some authors observed how some churches in Fiji motivate intensive collective work (e.g., new taro cultivation and the temporary opening of marine protected areas for intensive fishing) to raise funds for church activities or expansion. Some authors also observed some church members in Pacific Islands intensifying their harvesting of marine resources so they can make larger financial contributions to the church.

In the Federated States of Micronesia (FSM), the Republic of Palau, and the Republic of the Marshall Islands, leaders use an integrative approach that combines ILK, other scientific knowledge systems, and planning. In Pohnpei (FSM), the concept 
is called engine kehlap (collective effort), and it has been revived to guide collaboration among government (customary and elected leaders), nongovernment, and other groups with regard to resource management under accelerating environmental change (Apis-Overhoff, unpublished data). The traditional concept has retained its power from the past and offers a framework for promoting the integration of all available systems to address local issues using culturally appropriate means. ILK should be applied thoughtfully and carefully because local leaders with expertise in ILK can lose esteem and power, for example, when their ILK becomes less reliable under increasingly unpredictable weather (Kronik and Verner 2010), and government leaders with top-down approaches to adaptation can be unrealistic and inefficient. However, collaboration among leaders can strengthen governance and adaptation approaches.

\section{Social institutions, social networks, and resilience}

Indicators of resilience in social-ecological systems include respected leaders (whether they are influential elders or college graduates) that encourage self-organization (Ostrom 2009), social networks and governance based in ILK (Adger 2003, Ford et al. 2008, Prno et al. 2011), and institutional diversity (Adger 2003, Dietzet al. 2003, Ostrom 2009; Fig. 1). Institutions that present a range of ways to structure rules for resource use, monitoring, and enforcement, with institutions that are "complex, redundant, and nested in many layers" (Dietz et al. 2003:1912) from the local to the international (Folke et al. 2002), are most effective. Leaders with ILK are an important part of this diversity (Fig. 1). We recommend research to explore the dynamics among leadership roles (i.e., customary, church, government, and nonprofit), institutional diversity, and resilience to climate change. We also recommend research to explore how integrated, culturally appropriate adaptation strategies that include ILK and build on customary governance structures can best be implemented and disseminated. There is a need to explore how adaptation measures can foster effective management and social resilience by incorporating ILK, while also involving women, youth, and nearby nonindigenous communities (Box 1). For example, in Fiji, nongovernmental organizations are training local resource committee members to "draw upon both traditional ecological knowledge as well as scientific information to communicate [local management rules] effectively in the village setting, particularly to target groups such as women and youth who have been previously underrepresented in past management planning workshops." (Jupiter et al. 2012a:159).

As important elements of social-ecological systems, social networks and institutions can promote the three defining characteristics of resilience (Resilience Alliance, http://www. resalliance.org/index.php/resilience). They can buffer disturbance (e.g., through reciprocal exchange), promote self-organization (e.g., through local leadership), and facilitate social learning (for example, by serving as cumulative memory of a community's experience over an extended time period; Fig. 1). Social institutions and networks create, enforce, and foster the continuation of rules and the associated values and knowledge (Turner and Berkes 2006), as well as resource management, access, and use. Institutions that are able to adapt and respond to changing circumstances (e.g., allowing the relaxing of tenure in times of crisis) are more resilient than rigid ones (e.g., Forbes et al. 2009, Lauer et al. 2012).

Supported by navigational knowledge and seafaring abilities, Pacific Islanders have developed social institutions and networks that promote the inter-island distribution of resources and connect people across land and vast expanses of water, and between nations (Alkire 1978, Thaman 2002, D'Arcy 2006). They have also developed intra-island networks, which have been vital for resource redistribution and cooperation (Mills 2005, Campbell 2009). Over many centuries, these exchange networks have facilitated the adaptation to local resource deficiencies under everyday circumstances and during crises by buffering the effects of disruption in resource availability due to storms, volcanic eruption, and sea-level rise (Ellen 2007, Thaman 2008).

In addition to managing resource distribution, social institutions and social networks also facilitate information exchange and knowledge transmission, specifically as it concerns ecosystem management (Olsson et al. 2004), the establishment and maintenance of customary resource management (Adger 2003), mobilizing collective responses to disturbance (Turner and Clifton 2009, Gómez-Baggethun et al. 2012), and thus, promoting adaptability to climate change (Adger 2003, Ford et al. 2008, Prno et al. 2011; Fig. 1). An important aspect of resilience to climate change is food security (Colding et al. 2008), which is supported by practices of reciprocity (e.g., with affines and/or consanguines), economic exchanges, and through barter and markets.

In Pacific Islands, reciprocity and social alliances have been established and maintained through ritualized exchanges of culturally salient items such as food (e.g., yams) and textiles (e.g., tapa or barkcloth and woven mats). Although ritual exchange networks are no longer practiced as they once were (Thaman et al. 2002), remittances can be seen as a modern practice of resource redistribution that maintain social connections (Rasmussen et al. 2009, Barnett and Campbell 2010), both under normal circumstances as well as in times of crisis. In 2011, an estimated $\$ 137$ million (USD) in remittances were sent to Samoa, \$65 million of which were from New Zealand, the country with the largest share of Samoans living abroad (World Bank 2012). Notable amounts of remittances from New Zealand to Samoa also followed Samoa's 1990 cyclone (Barnett and Campbell 2010) and 2009 tsunami (Gibson 2010). It is important to point out that this flow of resources is not unidirectional. While money is sent home, culturally significant goods (e.g., traditional foods) are sent abroad, keeping the diasporic community rooted in the home culture and maintaining the network. There is a need to explore current practices of reciprocity and social network exchanges because many are informal and undocumented. There is also a need to examine the relationship between practices of reciprocity and engagement in a cash or market economy. It is hypothesized that deeper engagement in a cash economy weakens practices of reciprocity (e.g., Lauer et al. 2012) and the links in social networks because it negates the need to share and encourages more resource extraction for the purposes of selling, but to our knowledge this has not been tested (Box 1).

Cooperative behavior and interdependence are reinforced through cultural values. A culture's worldview mediates its interconnected set of ILK, resource management practices, social 
networks, and social institutions (Berkes and Turner 2006; Fig. 1). In Pacific Islands, the act of giving has been a sign of prestige (for example, Malinowski 1922). Rather than being an accumulation of property, wealth can be a reflection of creating obligations that can be called upon at times of need. On Simbo (Solomon Islands), reciprocal obligations are maintained through varivagana, a concept that "connotes love, a feeling of concern for other people, and maintaining community relationships" (Lauer et al. 2012:44). Following the 2007 tsunami, this ethos supported Simbo Islanders' recovery by promoting the redistribution and sharing of resources such as planting space, building materials, and foods, including those that otherwise would have been restricted under customary tenure (Lauer et al. 2012). Similar exchanges have taken place elsewhere in the Pacific Islands after extreme events (Thaman et al. 2002, Campbell 2009). As noted by Kronik and Verner (2010:162), "Cultural values that deal with uncertainty and variability, developed within indigenous peoples' institutions over time, may be the main contribution in developing adaptation and mitigation strategies" (Fig. 1). These aspects of ILK systems are not peripheral. They are integrated and all-encompassing.

In addition to providing data to inform the understanding of change, ILK's associated worldviews, perspectives of the environment, and value systems are instructive for guiding how humans interact with and adapt to our natural environment (e.g., Turner and Berkes 2006, Burkett 2013, Leonard et al. 2013; Fig. 1). We strongly discourage selecting aspects of ILK (i.e., empirical observations) to include in scientific research and disassociating them from the worldviews and cultural values that undergird them. To do so misrepresents the knowledge systems and imposes a framework that may not be consistent with the local paradigm. Therefore, we recommend research to prioritize the identification of cultural values and associated practices that promote resilience as well as how to integrate them into adaptation communication and planning (Box 1).

\section{Limitations}

While there exists great potential in learning from ILK to promote resilience to the effects of climate change, there are limitations. These include:

- A lack of prior experience of change at this pace and magnitude. Although ILK systems are recognized for their adaptive capacity under past conditions, the rapid pace at which social, economic, and ecological changes are occurring might mean that ILK systems are unable to adapt quickly enough to prevent significant impacts (e.g., Nunn 2009).

- A loss of ILK over time. Colonial and religious institutions displaced, devalued, and in some cases, outlawed indigenous languages and practices (e.g., Wilson 1998). ILK was lost as a result. The effects of epidemics from the West to immunologically naive indigenous populations also displaced and decreased ILK at the community and island levels (Bushnell 1993).

- Many elements of ILK are strongly embedded in everyday social processes that have been modified through contact, colonialism, and now, globalization (e.g., Barnett and Campbell 2010). Elements of ILK may no longer be relevant in contemporary social contexts and might have fallen into disuse as a result. While this might be part of a normal process in dynamic knowledge systems, it means that ILK should not always be assumed to be relevant to resilience and adaptation.

- Shifting baselines. Local understandings of change, even those based in ILK with a long history, can be strongly influenced by a reference point of only a few generations previously. Although local fluctuations might be observed, they can be interpreted as within the range of normal variation, when longitudinal regional and global perspectives show otherwise (e.g., Albert et al 2013).

- Not all ILK is necessarily aimed at sustainability (e.g., Foale et al. 2011, Berkes 2012). In some cases, ILK is oriented toward maximizing resource extraction. It cannot be assumed that it is always sustainable.

- A loss of respect. Local leaders with expertise in ILK can lose esteem and power when their ILK becomes less reliable (e.g., Kronik and Verner 2010). In these cases, ILK might undermine authority or be an obstacle to effective governance.

\section{CONCLUSIONS}

Although Pacific Islands are small, their ILK systems include valuable insights that are relevant at broad scales for understanding resilience and adaptability to the social-ecological effects of climate change. ILK systems can contribute local-scale and high-resolution observations, benchmark data, and insights into practices that enhance biocultural diversity, social-ecological resilience, and adaptive capacity in integrated terrestrial and marine systems. Through community-based and participatory approaches, ILK can complement and ground-truth climate models and direct culturally appropriate resource management, research, and adaptation measures. There is a great opportunity to learn from these systems and to understand their limitations. We emphasize the need for a social-ecological systems approach, attention to biocultural diversity, and collaborations among and within government agencies (e.g., weather service, agriculture, forestry and fisheries departments, climate change offices, and disaster management offices), academic, nongovernment, and policy organizations, and local communities. We believe that such collaborations can enrich knowledge at local and global scales and inform adaptation strategies in meaningful ways. A cohesive regional approach is needed, not just among U.S.-affiliated islands, the French territories, or the member countries of the Pacific Climate Forum. We strongly reiterate the point that Liu et al. (2007a:1516) make: "It is critical to move beyond the existing approaches for studying coupled systems, to develop more comprehensive portfolios, and to build an international network for interdisciplinary research spanning local, regional, national, and global levels." There is also a need for increased sharing of findings in diverse ways. This can be facilitated by open-access data sharing policies as well as through enhanced communication in which findings are translated into community-appropriate materials and messages using local languages, concepts, and locally accessible technologies.

Responses to this article can be read online at: http://www.ecologyandsociety.org/issues/responses. $\mathrm{php} / 6937$ 


\section{Acknowledgments:}

The discussions during the "Hawaii-Fiji workshop on local ecological knowledge and social-ecological resiliency to climate change," held September 2-3, 2013 in Suva, Fiji, at the University of the South Pacific, provided inspiration for this paper, and we thank the participants, including the University of the South Pacific and University of Hawai i students, and the Econesian Society. This synthesis was funded in part by National Science Foundation grant OISE-1160830.

\section{LITERATURE CITED}

Acharya, S. 2011. Prediction of rainfall variation through flowering phenology of night-flowering jasmine (Nyctanthes arbor-tristis L ; Verbenaceae) in Tripura. Indian Journal of Traditional Knowledge 10(1):96-101. [online] URL: http://nopr. niscair.res.in/handle/123456789/11070.

Adger, W. N. 2003. Social capital, collective action, and adaptation to climate change. Economic Geography 79 (4):387-404.

Adger, W. N., T. P. Hughes, C. Folke, S. R. Carpenter, and J. Rockström. 2005. Social-ecological resilience to coastal disasters. Science 309:1036-1039. http://dx.doi.org/10.1126/science.1112122

Agrawal, A. 2010. Local institutions and adaptation to climate change. Pages 173-198 in R. Mearns and A. Norton, editors. Social dimensions of climate change: equity and vulnerability in a warming world. World Bank, Washington, D.C., USA.

Albert, S., M. Love, and T. D. Brewer. 2013. Contrasts in social and ecological assessments of coral reef health in Melanesia. Pacific Science 67(3):409-424. http://dx.doi.org/10.2984/67.3.8

Alcorn, J. B. 1989. Process as resource. Advances in Economic Botany 7:63-77.

Alexander, C., N. Bynum, E. Johnson, U. King, T. Mustonen, P. Neofotis, N. Oettlé, C. Rosenzweig, C. Sakakibara, V. Shadrin, M. Vicarelli, J. Waterhouse, and B. Weeks. 2011. Linking indigenous and scientific knowledge of climate change. BioScience 61(6):477-484. http://dx.doi.org/10.1525/bio.2011.61.6.10

Alkire, W. H. 1978. Coral islanders. AHM Publishing, Arlington Heights, Illinois, USA.

Altieri, M. A., M. K. Anderson, and L. C. Merrick. 1989. Peasant agriculture and the conservation of crop and wild plant resources. Conservation Biology 1(1):49-58. http://dx.doi.org/10.1111/ j.1523-1739.1987.tb00008.x

Baines, G. B. K. 1989. Traditional resource management in the Melanesian South Pacific: a development dilemma. Pages 273-295 in F. Berkes, editor. Community-based sustainable development: the ecology of common property resources. Belhaven, London, UK.

Barnes, J., M. Dove, M. Lahsen, A. Mathews, P. McElwee, R. McIntosh, F. Moore, J. O'Reilly, B. Orlove, R. Puri, H. Weiss, and K. Yager. 2013. Contribution of anthropology to the study of climate change. Nature Climate Change 3:541-544. http://dx.doi. org/10.1038/nclimate 1775
Barnett, J., and J. Campbell. 2010. Climate change and small island States: power, knowledge and the South Pacific. Earthscan, London, UK.

Bart, D. 2006. Integrating local ecological knowledge and manipulative experiments to find the causes of environmental change. Frontiers in Ecology and the Environment 4:541-546. http://dx.doi.org/10.1890/1540-9295(2006)4[541:ILEKAM]2.0.CO;2

Barthel, S., C. Crumley, and U. Svedin. 2013. Bio-cultural refugia - safeguarding diversity of practices for food security and biodiversity. Global Environmental Change 23(5):1142-1152. http://dx.doi.org/10.1016/j.gloenvcha.2013.05.001

Bell, J. D., A. Ganachaud, P. C. Gehrke, S. P. Griffiths, A. J. Hobday, O. Hoegh-Guldberg, J. E. Johnson, R. LeBorgne, P. Lehodey, J. M. Lough, R. J. Matear, T. D. Pickering, M. S. Pratchett, A. S. Gupta, I. Senina, and M. Waycott. 2013. Mixed responses of tropical Pacific fisheries and aquaculture to climate change. Nature Climate Change 3:591-599. http://dx.doi. org/10.1038/nclimate 1838

Bellwood, D. R., T. P. Hughes, C. Folke, and M. Nyström. 2004. Confronting the coral reef crisis. Nature 429:827-833. http://dx. doi.org/10.1038/nature02691

Berkes, F. 1999. Sacred ecology. Taylor and Francis, Philadelphia, Pennsylvania, USA.

Berkes, F. 2009. Indigenous ways of knowing and the study of environmental change. Journal of the Royal Society of New Zealand 39(4):151-156. http://dx.doi.org/10.1080/03014220909510568

Berkes, F. 2012. Sacred ecology. Third edition. Routledge, London, UK.

Berkes, F., and D. Jolly. 2001. Adapting to climate change: socialecological resilience in a Canadian western Arctic community. Conservation Ecology 5(2): 18. [online] URL: http://www. consecol.org/vol5/iss2/art18/.

Berkes, F., and N. J. Turner. 2006. Knowledge, learning and the evolution of conservation practice for social-ecological system resilience. Human Ecology 34(4):479-494. http://dx.doi. org/10.1007/s10745-006-9008-2

Bird, R. B., B. F. Codding, P. G. Kauhanen, and D. W. Bird. 2012. Aboriginal hunting buffers climate-driven fire-size variability in Australia's spinifex grasslands. Proceedings of the National Academy of Sciences 109(26):10287-10292. http://dx.doi. org/10.1073/pnas.1204585109

Blaisdell, R. K., J. K. Lake, and H. K. Chang. 2005. Cover essay: Ka Ahupua'a. EcoHealth 2(4):373-375. http://dx.doi.org/10.1007/ $\underline{\mathrm{s} 10393-005-8932-8}$

Brewer, T. D., J. E. Cinner, R. Fisher, A. Green, and S. K. Wilson. 2012. Market access, population density, and socioeconomic development explain diversity and functional group biomass of coral reef fish assemblages. Global Environmental Change 22 (2):399-406. http://dx.doi.org/10.1016/j.gloenvcha.2012.01.006

Bridges, K. W., and W. C. McClatchey. 2009. Living on the margin: ethnoecological insights from Marshall Islanders at Rongelap Atoll. Global Environmental Change 19(2):140-146. http://dx.doi. org/10.1016/j.gloenvcha.2009.01.009 
Burkett, M. 2013. Indigenous environmental knowledge and climate change adaptation. Pages 96-118 In R. S. Abate and E. A. Kronk, editors. Climate change and indigenous peoples: the search for legal remedies. Edward Elgar, Cheltenham, UK. http:// dx.doi.org/10.4337/9781781001806.00014

Bushnell, O. A. 1993. The gifts of civilization: germs and genocide in Hawai $i$. University of Hawai i i Press, Honolulu, Hawai' i, USA.

Campbell, J. R. 2006. Traditional disaster reduction in Pacific Island communities. GNS Science Report 2006/38. GNS Science, Wellington, New Zealand.

Campbell, J. 2009. Islandness: vulnerability and resilience in Oceania. Shima: the International Journal of Research into Island Cultures 3(1):85-97.

Carpenter, S. R., and W. A. Brock. 2008. Adaptive capacity and traps. Ecology and Society 13(2): 40. [online] URL: http://www. ecologyandsociety.org/vol13/iss2/art40/.

Chapman, M. D. 1987. Women's fishing in Oceania. Human Ecology 15(3):267-288. http://dx.doi.org/10.1007/BF00888026

Chaudhary, P., and K. S. Bawa. 2011. Local perceptions of climate change validated by scientific evidence in the Himalayas. Biology Letters 7(5):767-770. http://dx.doi.org/10.1098/rsbl.2011.0269

Cinner, J. E., and S. Aswani. 2007. Integrating customary management into marine conservation. Biological Conservation 140:201-216. http://dx.doi.org/10.1016/j.biocon.2007.08.008

Cinner, J. E., T. R. McClanahan, M. A. MacNeil, N. A. J. Graham, T. M. Daw, A. Mukminin, D. A. Feary, A. L. Rabearisoa, A. Wamukota, N. Jiddawi, S. J. Campbell, A. H. Baird, F. A. Januchowski-Hartley, S. Hamed, R. Lahari, T. Morove, and J. Kuange. 2012. Comanagement of coral reef social-ecological systems. Proceedings of the National Academy of Sciences 109 (14):5219-5222. http://dx.doi.org/10.1073/pnas.1121215109

Clarke, W. C., and R. R. Thaman, editors. 1993. Pacific Island agroforestry: systems for sustainability. United Nations University Press, Tokyo, Japan.

Cohen, P. J., and S. J. Foale. 2013. Sustaining small-scale fisheries with periodically harvested marine reserves. Marine Policy 37:278-287. http://dx.doi.org/10.1016/j.marpol.2012.05.010

Colding, J., T. Elmqvist, and P. Olsson. 2002. Living with disturbance: building resilience in social-ecological systems. Pages 163-186 in F. Berkes, J. Colding, and C. Folke, editors. Navigating social-ecological systems: building resilience for complexity and change. Cambridge University Press, Cambridge, UK. http://dx. doi.org/10.1017/CBO9780511541957.011

Costa-Pierce, B. A. 2002. The Ahupua'a aquaculture ecosystems in Hawai i. Pages 30-43 in B. A. Costa-Pierce, editor. Ecological aquaculture: the evolution of the blue revolution. Wiley-Blackwell, Oxford, UK.

Cruikshank, J. 2001. Glaciers and climate change: perspectives from oral tradition. Arctic 54(4):377-393. http://dx.doi. org/10.14430/arctic795

D'Arcy, P. 2006. The people of the sea: environment, identity, and history in Oceania. University of Hawai' i Press, Honolulu, Hawai'i, USA.
Danielsen, F., N. D. Burgess, P. M. Jensen, and K. Pirhofer-Walzl. 2010. Environmental monitoring: the scale and speed of implementation varies according to the degree of peoples involvement. Journal of Applied Ecology 47(6):1166-1168. http:// dx.doi.org/10.1111/j.1365-2664.2010.01874.x

Dietz, T., E. Ostrom, and P. C. Stern. 2003. The struggle to govern the commons. Science 302(5652):1907-1912. http://dx.doi. org/10.1126/science.1091015

Dieudonne, F., J. M. Farber, and S. Halapua, editors. 2002. The Pacific Islands and the sea: 350 years of reporting on royal fishponds, coral reefs and ancient walled fish weirs in Oceania. Neptune House, Encinitas, California, USA.

Duffy, D. C. 2011. No room in the ark? Climate change and biodiversity in the Pacific Islands of Oceania. Pacific Conservation Biology 17(3):192-200.

Eisner, W. R., J. Jelacic, C. J. Cuomo, C. Kim, K. M. Hinkel, and D. Del Alba. 2012. Producing an indigenous knowledge Web GIS for Arctic Alaska communities: challenges, successes, and lessons learned. Transactions in GIS 16(1):17-37. http://dx.doi. org/10.1111/j.1467-9671.2011.01291.x

Ellen, R. 2007. Introduction. Pages 1-45 in R. Ellen, editor. Modern crises and traditional strategies: local ecological knowledge in island Southeast Asia. Berghahn, New York, New York, USA.

Englberger, L., W. Aalbersberg, P. Ravi, E. Bonnin, G. C. Marks, M. H. Fitzgerald, and J. Elymore. 2003. Further analyses on Micronesian banana, taro, breadfruit and other foods for provitamin A carotenoids and minerals. Journal of Food Composition and Analysis 16(2):219-236. http://dx.doi.org/10.1016/ S0889-1575(02)00171-0

Erdland, A. 1914. The Marshall Islanders: life and customs, thought and religion of a South Seas people. Translated from the German by Richard Nouse, (1961). Aschendorff, Münster, Germany.

FAO [Food and Agriculture Organization]. 2010. Building resilience to climate change: root crop and fisheries production. FAO, Rome, Italy. [online] URL: http://www.fao.org/docrep/013/ am014e/am014e.pdf.

Finney, B. R. 1977. Voyaging canoes and the settlement of Polynesia. Science 196(4296):1277-1285. http://dx.doi.org/10.1126/ science.196.4296.1277

Finney, B. 1998. Traditional navigation and nautical cartography in Oceania. Pages 443-492 in D. Woodward and G. M. Lewis, editors. Cartography in the traditional African, American, Arctic, Australian, and Pacific Societies. University of Chicago Press, Chicago, Illinois, USA.

Finney, B. R. 2003. Sailing in the wake of the ancestors: reviving Polynesian voyaging. Bishop Museum Press, Honolulu, Hawai'i, USA.

Finney, B., and S. Low. 2006. Navigation. Pages 154-197 in K. R. Howe. Vaka Moana: voyages of the ancestors. The discovery and settlement of the Pacific. Auckland War Memorial Museum, Auckland, New Zealand. 
FLMMA [Fiji Locally Managed Marine Areas Network]. 2011. The way we work together: guidelines for members of the FLMMA network. FLMMA operations guide. Final 1.7. Institute of Applied Sciences, University of the South Pacific, Suva, Fiji. [online] URL: http://www.Immanetwork.org/files/fiji/flmma operations guide. doc.

Foale, S., P. Cohen, S. Januchowski-Hartley, A. Wenger, and M. Macintyre. 2011. Tenure and taboos: origins and implications for fisheries in the Pacific. Fish and Fisheries 12(4):357-369. http://dx. doi.org/10.1111/j.1467-2979.2010.00395.x

Folke, C., J. Colding, and F. Berkes. 2003. Synthesis: building resilience and adaptive capacity in social-ecological systems. Pages 352-388 in F. Berkes, J. Colding, and C. Folke, editors. Navigating social-ecological systems: building resilience for complexity and change. Cambridge University Press, Cambridge, UK.

Folke, C., S. Carpenter, T. Elmqvist, L. Gunderson, C. S. Holling, and B. Walker. 2002. Resilience and sustainable development: building adaptive capacity in a world of transformations. Ambio 31(5):437-440. http://dx.doi.org/10.1579/0044-7447-31.5.437

Forbes, B. C., F. Stammler, T. Kumpula, N. Meschtyb, A. Pajunen, and E. Kaarlejärvi. 2009. High resilience in the Yamal-Nenets social-ecological system, west Siberian Arctic, Russia. Proceedings of the National Academy of Sciences 106 (52):22041-22048. http://dx.doi.org/10.1073/pnas.0908286106

Ford, J. D., T. Pearce, J. Gilligan, B. Smit, and J. Oakes. 2008. Climate change and hazards associated with ice use in northern Canada. Arctic, Antarctic, and Alpine Research 40(4):647-659. http://dx.doi.org/10.1657/1523-0430(07-040)[FORD]2.0.CO;2

Friedlander, A. M., and E. E. DeMartini. 2002. Contrasts in density, size, and biomass of reef fishes between the northwestern and the main Hawaiian islands: the effects of fishing down apex predators. Marine Ecology Progress Series 230:253-264. http://dx. doi.org/10.3354/meps230253

Friedlander, A. M., J. M. Shackleroff, and J. N. Kittinger 2013. Customary marine resource knowledge and use in contemporary Hawai'i. Pacific Science 67(3):441-460. http://dx.doi.org/10.2984/67.3.10

Garza, J. A., P.-S. Chu, C. W. Norton, and T. A. Schroeder. 2012. Changes of the prevailing trade winds over the islands of Hawaii and the North Pacific. Journal of Geophysical Research: Atmospheres 117(D11): D11109. http://dx.doi.org/10.1029/2011JD016888

Genz, J. 2011. Navigating the revival of voyaging in the Marshall Islands: predicaments of preservation and possibilities of collaboration. Contemporary Pacific 23(1):1-34. http://dx.doi. org/10.1353/cp.2011.0017

Gibson, J. 2010. Recent shocks and long-term change in the Samoan economy. Pacific Economic Bulletin 25(3):6-23.

Golbuu, Y., E. Wolanski, P. Harrison, R. H. Richmond, S. Victor, and K. E. Fabricius. 2011. Effects of land-use change on characteristics and dynamics of watershed discharges in Babeldaob, Palau, Micronesia. Journal of Marine Biology 2011: 981273. http://dx.doi.org/10.1155/2011/981273

Gombos, M., S. Atkinson, and S. Wongbusarakum. 2013. Adapting to a changing climate: guide to local early action planning
(LEAP) and management planning. Micronesia Conservation Trust, Pohnpei, Federated States of Micronesia. [online] URL: https://static.weadapt.org/knowledge-base/files/1344/5342cc6b82c1dadapting-to-a-changing-climate-final-dec.-2013.pdf.

Gómez-Baggethun, E., V. Reyes-García, P. Olsson, and C. Montes. 2012. Traditional ecological knowledge and community resilience to environmental extremes: a case study in Doñana, SW Spain. Global Environmental Change 22(3):640-650. http://dx.doi. org/10.1016/j.gloenvcha.2012.02.005

Gorenflo, L. J., S. Romaine, R. A. Mittermeier, and K. WalkerPainemilla. 2012. Co-occurrence of linguistic and biological diversity in biodiversity hotspots and high biodiversity wilderness areas. Proceedings of the National Academy of Sciences 109 (21):8032-8037. http://dx.doi.org/10.1073/pnas.1117511109

Govan, H., editor. 2009. Status and potential of locally-managed marine areas in the Pacific Island region: meeting nature conservation and sustainable livelihood targets through wide-spread implementation of LMMAs. Coral Reef Initiatives for the Pacific (CRISP), Noumea, France. [online] URL: http://mpra.ub.unimuenchen.de/23828/1/MPRA paper 23828.pdf.

Grantham, H. S., E. McLeod, A. Brooks, S. D. Jupiter, J. Hardcastle, A. J. Richardson, E. S. Poloczanska, T. Hills, N. Mieszkowska, C. J. Klein, and J. E. M. Watson. 2011. Ecosystembased adaptation in marine ecosystems of tropical Oceania in response to climate change. Pacific Conservation Biology 17:241-258.

Green, D., J. Billy, and A. Tapim. 2010. Indigenous Australians' knowledge of weather and climate. Climatic Change 100 (2):337-354. http://dx.doi.org/10.1007/s10584-010-9803-z

Gunderson, L. H., and C. S. Holling, editors. 2002. Panarchy: understanding transformations in human and natural systems. Island Press, Washington, D.C., USA.

Hau'ofa, E. 1994. Our sea of islands. Contemporary Pacific 6 (1):147-161. [online] URL: http://hdl.handle.net/10125/12960.

Holling, C. S. 2001. Understanding the complexity of economic, ecological, and social systems. Ecosystems 4(5):390-405. http:// dx.doi.org/10.1007/s10021-001-0101-5

Howe, K. R., editor. 2006. Vaka Moana: voyages of the ancestors. The discovery and settlement of the Pacific. Auckland War Memorial Museum, Auckland, New Zealand.

Hughes, T. P., M. J. Rodrigues, D. R. Bellwood, D. Ceccarelli, O. Hoegh-Guldberg, L. McCook, N. Moltschaniwskyj, M. S. Pratchett, R. S. Steneck, and B. Willis. 2007. Phase shifts, herbivory, and the resilience of coral reefs to climate change. Current Biology 17(4):360-365. http://dx.doi:10.1016/j.cub.2006.12.049

Huntington, H. P., S. Gearheard, A. R. Mahoney, and A. K. Salomon. 2011. Integrating traditional and scientific knowledge through collaborative natural science field research: identifying elements for success. Arctic 64(4):437-445. http://dx.doi org/10.14430/arctic4143

Hviding, E. 1996. Guardians of Marovo Lagoon: practice, place, and politics in maritime Melanesia. Pacific Islands Monograph Series 14. University of Hawai'i Press, Honolulu, Hawai i, USA. 
IUCN [International Union for the Conservation of Nature]. 2013. IUCN Red List of Threatened Species 2013. IUCN, Cambridge, UK. [online] URL: http://www.iucnredlist.org/.

Jacob, C., T. McDaniels, and S. Hinch. 2010. Indigenous culture and adaptation to climate change: sockeye salmon and the St'át'imc people. Mitigation and Adaptation Strategies for Global Change 15(8):859-876. http://dx.doi.org/10.1007/s11027-010-9244$\underline{\mathrm{Z}}$

Johannes, R. E. 1978. Traditional marine conservation methods in Oceania and their demise. Annual Review of Ecology and Systematics 9:349-364. http://dx.doi.org/10.1146/annurev. es.09.110178.002025

Johannes, R. E. 1981. Words of the lagoon: fishing and marine lore in the Palau district of Micronesia. University of California Press, Berkeley, California, USA.

Johannes, R. E. 1997. Traditional coral-reef fisheries management. Pages 380-385 in C. Birkeland, editor. Life and death of coral reefs. Chapman and Hall, New York, New York, USA.

Johannes, R. E. 2002. The renaissance of community-based marine resource management in Oceania. Annual Review of Ecology and Systematics 33:317-340. http://dx.doi.org/10.1146/ annurev.ecolsys.33.010802.150524

JSSA [Japan Satoyama Satoumi Assessment]. 2010. SatoyamaSatoumi ecosystems and human well-being: socio-ecological production landscapes of Japan - summary for decision makers. United Nations University, Tokyo, Japan. [online] URL: http:// www.ias.unu.edu/resource centre/SDM-EN_24Feb2011.pdf.

Jupiter, S. D., P. J. Cohen, R. Weeks, A. Tawake, and H. Govan. 2014. Locally-managed marine areas: multiple objectives and diverse strategies. Pacific Conservation Biology 20(2):165-179.

Jupiter, S., C. McClennen, and E. Matthews. 2012a. Vatu-i-Ra seascape, Fiji. Pages 155-169 in J. A. Hilty, C. C. Chester, and M. S. Cross, editors. Climate and conservation: landscape and seascape science, planning and action. Island Press, Washington, D.C., USA.

Jupiter, S. D., R. Weeks, A. P. Jenkins, D. P. Egli, and A. Cakacaka. 2012b. Effects of a single intensive harvest on fish populations inside a customary marine closure. Coral Reefs 31:321-334. http:// dx.doi.org/10.1007/s00338-012-0888-X

Keener, V. W., J. J. Marra, M. L. Finucane, D. Spooner, and M. H. Smith, editors. 2012. Climate change and Pacific Islands: indicators and impacts. Report for the 2012 Pacific Islands regional climate assessment (PIRCA). Island Press, Washington, D.C., USA.

King, D. N. T., A. Skipper, and W. B. Tawhai. 2008. Māori environmental knowledge of local weather and climate change in Aotearoa - New Zealand. Climatic Change 90(4):385-409. http:// dx.doi.org/10.1007/s10584-007-9372-y

Kingsford, R. T., and S. D. Jupiter. 2014. Conservation lessons from the Pacific Islands. Pacific Conservation Biology 20 (2):134-135.

Kirch, P. V., and R. C. Green. 2001. Hawaiki, ancestral Polynesia: an essay in historical anthropology. Cambridge University Press, Cambridge, UK. http://dx.doi.org/10.1017/CBO9780511613678
Kronik, J., and D. Verner. 2010. The role of indigenous knowledge in crafting adaptation and mitigation strategies for climate change in Latin America. Pages 145-172 in R. Mearns and A. Norton, editors. Social dimensions of climate change: equity and vulnerability in a warming world. World Bank, Washington, D.C., USA. [online] URL: http://hdl.handle.net/10986/2689.

Krushelnycky, P. D., L. L. Loope, T. W. Giambelluca, F. Starr, K. Starr, D. R. Drake, A. D. Taylor, and R. H. Robichaux. 2013. Climate-associated population declines reverse recovery and threaten future of an iconic high-elevation plant. Global Change Biology 19(3):911-922. http://dx.doi.org/10.1111/gcb.12111

Lauer, M., S. Albert, S. Aswani, B. S. Halpern, L. Campanella, and D. La Rose. 2012. Globalization, Pacific Islands, and the paradox of resilience. Global Environmental Change 23(1):40-50. http://dx.doi.org/10.1016/j.gloenvcha.2012.10.011

Leach, E. R. 1950. Primitive calendars. Oceania 20(4):245-262.

Lefale, P. F. 2010. Ua 'afa le aso stormy weather today: traditional ecological knowledge of weather and climate. The Samoa experience. Climatic Change 100(2):317-335. http://dx.doi. org/10.1007/s10584-009-9722-Z

Leonard, S., M. Parsons, K. Olawsky, and F. Kofod. 2013. The role of culture and traditional knowledge in climate change adaptation: insights from East Kimberley, Australia. Global Environmental Change 23(3):623-632. http://dx.doi.org/10.1016/ j.gloenvcha.2013.02.012

Lewis, D. 1994. We, the navigators: the ancient art of landfinding in the Pacific. Second edition. University of Hawai'i Press, Honolulu, Hawai' i, USA.

Lewis, M. P., G. F. Simons, and C. D. Fenning, editors. 2014. Ethnologue: languages of the world. Seventeenth edition. SIL International, Dallas, Texas, USA. [online] URL: http://www. ethnologue.com.

Liu, J., T. Dietz, S. R. Carpenter, M. Alberti, C. Folke, E. Moran, A. N. Pell, P. Deadman, T. Kratz, J. Lubchenco, E. Ostrom, Z. Ouyang, W. Provencher, C. L. Redman, S. H. Schneider, and W. W. Taylor. 2007a. Complexity of coupled human and natural systems. Science 317:1513-1516. http://dx.doi.org/10.1126/ science. 1144004

Liu, J., T. Dietz, S. R. Carpenter, C. Folke, M. Alberti, C. L. Redman, S. H. Schneider, E. Ostrom, A. N. Pell, J. Lubchenco, W. W. Taylor, Z. Ouyang, P. Deadman, T. Kratz, and W. Provencher. 2007b. Coupled human and natural systems. Ambio 36(8):639-649. http://dx.doi.org/10.1579/0044-7447(2007)36[639: CHANS]2.0.CO;2

Lutchman, I., W. Aalbersberg, D. Hinchley, G. Miles, A. Tiraa, and S. Wells, editors. 2005. Marine protected areas: benefits and costs for islands. WWF, Zeist, The Netherlands.

Mahoney, A., S. Gearheard, T. Oshima, and T. Qillaq. 2009. Sea ice thickness measurements from a community-based observing network. Bulletin of the American Meteorological Society 90 (3):370-377. http://dx.doi.org/10.1175/2008BAMS2696.1

Maina, J., T. R. McClanahan, V. Venus, M. Ateweberhan, and J. Madin. 2011. Global gradients of coral exposure to environmental stresses and implications for local management. 
PLoS One 6: e23064. http://dx.doi.org/10.1371/journal. pone.0023064

Malinowski, B. 1922. Argonauts of the western Pacific. Routledge, New York, New York, USA.

Malinowski, B. 1927. Lunar and seasonal calendar in the Trobriands. Journal of the Royal Anthropological Institute of Great Britain and Ireland 57:203-215. http://dx.doi.org/10.2307/2843682

Marin, A. 2010. Riders under storms: contributions of nomadic herders' observations to analysing climate change in Mongolia. Global Environmental Change 20(1):162-176. http://dx.doi. org/10.1016/j.gloenvcha.2009.10.004

McAdoo, B. G., A. Moore, and J. Baumwoll. 2009. Indigenous knowledge and the near field population response during the 2007 Solomon Islands tsunami. Natural Hazards 48(1):73-82. http:// dx.doi.org/10.1007/s11069-008-9249-z

McClanahan, T. R., S. D. Donner, J. A. Maynard, M. A. MacNeil, N. A. J. Graham, J. Maina, A. C. Baker, J. B. Alemu, M. Beger, S. J. Campbell, E. S. Darling, C. M. Eakin, S. F. Heron, S. D. Jupiter, C. J. Lundquist, E. McLeod, P. J. Mumby, M. J. Paddack, E. R. Selig, and R. van Woesik. 2012. Prioritizing key resilience indicators to support coral reef management in a changing climate. PLoS One 7(8): e42884. http://dx.doi.org/10.1371/ journal.pone.0042884

Mercer, J. 2010. Disaster risk reduction or climate change adaptation: Are we reinventing the wheel? Journal of International Development 22(2):247-264. http://dx.doi.org/10.1002/jid.1677

Mercer, J., D. Dominey-Howes, I. Kelman, and K. Lloyd. 2007. The potential for combining indigenous and western knowledge in reducing vulnerability to environmental hazards in small island developing states. Environmental Hazards 7(4):245-256. http://dx. doi.org/10.1016/j.envhaz.2006.11.001

Mijatović, D., F. van Oudenhoven, P. Eyzaguirre, and T. Hodgkin. 2013. The role of agricultural biodiversity in strengthening resilience to climate change: towards an analytical framework. International Journal of Agricultural Sustainability 11(2):95-107. http://dx.doi.org/10.1080/14735903.2012.691221

Mills, P. R. 2005. Social integration and the Ala Loa: reconsidering the significance of trails in Hawaiian exchange. Asian Perspectives 41(1):148-166. http://dx.doi.org/10.1353/ asi. 2002.0008

Mirima Council. 2011. Miriwoong seasonal calendar. Mirima Council, Kununurra, Australia. [online] URL: http://www. mirima.org.au/calendar/.

Mondragón, C. 2004. Of winds, worms and mana: the traditional calendar of the Torres Islands, Vanuatu. Oceania 74(4):289-309.

Mora, C., A. G. Frazier, R. J. Longman, R. S. Dacks, M. M. Walton, E. J. Tong, J. J. Sanchez, L. R. Kaiser, Y. O. Stender, J. M. Anderson, C. M. Ambrosino, I. Fernandez-Silva, L. M. Giuseffi, and T. W. Giambelluca. 2013. The projected timing of climate departure from recent variability. Nature 502 (7470):183-187. http://dx.doi.org/10.1038/nature12540

Mumby, P. J. 2009. Phase shifts and the stability of macroalgal communities on Caribbean coral reefs. Coral Reefs 28(3):761-773. http://dx.doi.org/10.1007/s00338-009-0506-8
Mumby, P. J., A. Hastings, and H. J. Edwards. 2007. Thresholds and the resilience of Caribbean coral reefs. Nature 450:98-101. http://dx.doi.org/10.1038/nature06252

Mumby, P. J., N. H. Wolff, Y.-M. Bozec, I. Chollett, and P. Halloran. 2013. Operationalizing the resilience of coral reefs in an era of climate change. Conservation Letters 7(3):176-187. http://dx.doi.org/10.1111/conl.12047

Nakashima, D. J., K. Galloway McLean, H. D. Thulstrup, A. Ramos Castillo, and J. H. H. Toll. 2012. Weathering uncertainty: traditional knowledge for climate change assessment and adaptation. UNESCO, Paris, France.

Nelson, D. R., W. N. Adger, and K. Brown. 2007. Adaptation to environmental change: contributions of a resilience framework. Annual Review of Environment and Resources 32:395-419. http:// dx.doi.org/10.1146/annurev.energy.32.051807.090348

Nunn, P. D. 2009. Responding to the challenges of climate change in the Pacific Islands: management and technological imperatives. Climate Research 40(2-3):211-231. http://dx.doi.org/10.3354/ $\underline{\mathrm{cr} 00806}$

Nyström, M., N. A. J. Graham, J. Lokrantz, and A. V. Norström. 2008. Capturing the cornerstones of coral reef resilience: linking theory to practice. Coral Reefs 27(4):795-809. http://dx.doi. org/10.1007/s00338-008-0426-Z

Olsson, P., C. Folke, and F. Berkes. 2004. Adaptive comanagement for building resilience in social-ecological systems. Environmental Management 34(1):75-90. http://dx.doi.org/10.1007/s00267-003-0101-7

Orcherton, D. F. 2011. Raising the bar: recognizing the intricacies of cultural and ecological knowledge (CEK) in natural resource management. Journal of Ecosystems and Management 12 (3):55-82. [online] URL: http://jem.forrex.org/index.php/jem/ article/view/48/102.

Orlove, B. 2003. How people name seasons. Pages 121-140 in S. Strauss and B. S. Orlove, editors. Weather, climate, culture. Berg, Oxford, UK.

Ostrom, E. 2009. A general framework for analyzing sustainability of social-ecological systems. Science 325 (5939):419-422. http://dx.doi.org/10.1126/science.1172133

Patz, J. A., D. Campbell-Lendrum, T. Holloway, and J. A. Foley. 2005. Impact of regional climate change on human health. Nature 438:310-317. http://dx.doi.org/10.1038/nature04188

Pfund, J.-L., J. D. Watts, M. Boissière, A. Boucard, R. M. Bullock, A. Ekadinata, S. Dewi, L. Feintrenie, P. Levang, S. Rantala, D. Sheil, T. C. H. Sunderland, and Z. L. Urech. 2011. Understanding and integrating local perceptions of trees and forests into incentives for sustainable landscape management. Environmental Management 48(2):334-349. http://dx.doi.org/10.1007/s00267-011-9689-1

Poepoe, K., P. Bartram, and A. Friedlander. 2007. The use of traditional Hawaiian knowledge in the contemporary management of marine resources. Pages 117-141 in N. Haggan, B. Neis, and I. G. Baird, editors. Fishers' knowledge in fisheries science and management. UNESCO, Paris, France.

Price, C. 2009. Will a drier climate result in more lightning? Atmospheric Research 91(2-4):479-484. http://dx.doi.org/10.1016/ j.atmosres.2008.05.016 
Prno, J., B. Bradshaw, J. Wandel, T. Pearce, B. Smit, and L. Tozer. 2011. Community vulnerability to climate change in the context of other exposure-sensitivities in Kugluktuk, Nunavut. Polar Research 30: 7363. http://dx.doi.org/10.3402/polar.v30i0.7363

Prober, S. M., M. H. O’Connor, and F. J. Walsh. 2011. Australian Aboriginal peoples' seasonal knowledge: a potential basis for shared understanding in environmental management. Ecology and Society 16(2): 12. [online] URL: http://www.ecologyandsociety. org/vol16/iss2/art12/.

Quintero, M., S. Wunder, and R. D. Estrada. 2009. For services rendered? Modeling hydrology and livelihoods in Andean payments for environmental services schemes. Forest Ecology and Management 258(9):1871-1880. http://dx.doi.org/10.1016/j. foreco.2009.04.032

Rasher, D. B., S. Engel, V. Bonito, G. J. Fraser, J. P. Montoya, and M. E. Hay. 2012. Effects of herbivory, nutrients, and reef protection on algal proliferation and coral growth on a tropical reef. Oecologia 169(1):187-198. http://dx.doi.org/10.1007/ $\underline{\mathrm{s} 00442-011-2174-\mathrm{y}}$

Rasmussen, K., W. May, T. Birk, M. Mataki, O. Mertz, and D. Yee. 2009. Climate change on three Polynesian outliers in the Solomon Islands: impacts, vulnerability and adaptation. Geografisk Tidsskrift-Danish Journal of Geography 109(1):1-13. http://dx.doi.org/10.1080/00167223.2009.10649592

Raynor, W. C., and J. H. Fownes. 1991a. Indigenous agroforestry of Pohnpei 1. Plant species and cultivars. Agroforestry Systems 16(2):139-157. http://dx.doi.org/10.1007/BF00129745

Raynor, W. C., and J. H. Fownes. 1991b. Indigenous agroforestry of Pohnpei 2. Spatial and successional vegetation patterns. Agroforestry Systems 16(2):159-165. http://dx.doi.org/10.1007/ BF00129746

Republic of Vanuatu. 2011. Adaptation actions. National Advisory Board on Climate Change and Disaster Risk Reduction, Port Vila, Vanuatu.

Ruddle, K. 1998. The context of policy design for existing community-based fisheries management systems in the Pacific Islands. Ocean and Coastal Management 40(2):105-126. http://dx. doi.org/10.1016/S0964-5691(98)00040-4

Ruddle, K., and T. Akimichi, editors. 1984. Maritime institutions in the Western Pacific. Senri Ethnological Studies 17. National Museum of Ethnology, Osaka, Japan.

Rudiak-Gould, P. 2014. The influence of science communication on indigenous climate change perception: theoretical and practical implications. Human Ecology 42(1):75-86. http://dx.doi. org/10.1007/s10745-013-9605-9

Salick, J., and N. Ross. 2009. Traditional peoples and climate change. Global Environmental Change 19(2):137-139. http://dx. doi.org/10.1016/j.gloenvcha.2009.01.004

Sandin, S. A., J. E. Smith, E. E. DeMartini, E. A. Dinsdale, S. D. Donner, A. M. Friedlander, T. Konotchick, M. Malay, J. E. Maragos, D. Obura, O. Pantos, G. Paulay, M. Richie, F. Rohwer, R. E. Schroeder, S. Walsh, J. B. C. Jackson, N. Knowlton, and E. Sala. 2008. Baselines and degradation of coral reefs in the northern Line Islands. PLoS One 3(2): e1548. http://dx.doi. org/10.1371/journal.pone.0001548
Schmidt, I. B., and T. Ticktin. 2012. When lessons from matrix population models and local ecological knowledge coincide effects of flower stalk harvest in the Brazilian savanna. Biological Conservation 152:187-195. http://dx.doi.org/10.1016/j.biocon.2012.03.018

Sillitoe, P. 1994. Whether rain or shine: weather regimes from a New Guinea perspective. Oceania 64:246-270.

Smith, A. C. 1996. Flora vitensis nova. National Tropical Botanical Garden, Lawai, Hawai i, USA. [online] URL: http://ia700309.us. archive.org/28/items/floravitiensisno1996smit/floravitiensisno1996smit. pdf.

Tapia-Coral, S. C., F. J. Luizão, E. Wandelli, and E. C. M. Fernandes. 2005. Carbon and nutrient stocks in the litter layer of agroforestry systems in central Amazonia, Brazil. Agroforestry Systems 65(1):33-42. http://dx.doi.org/10.1007/s10457-004-5152-0

Thaman, R. R. 1976. The role of indigenous agricultural systems in fulfilling the needs of Pacific societies. Pages 35-52 in E. K. Fisk, J. B. Hardatek, and R. R. Thaman, editors. Food production in the South Pacific. R. W. Parkinson Memorial Lectures. University of the South Pacific, Suva, Fiji.

Thaman, R. 2002. Threats to Pacific Island biodiversity and biodiversity conservation in the Pacific Islands. Development Bulletin 58:23-27.

Thaman, R. R. 2008. Pacific Island agrobiodiversity and ethnobiodiversity: a foundation for sustainable Pacific Island life. Biodiversity and Agriculture 9(1-2):102-110. http://dx.doi. org/10.1080/14888386.2008.9712895

Thaman, R. R. 2009. Our biodiversity as food security. Mai Life May 2009, 46-48.

Thaman, R. R., A. Balawa, and T. Fong. 2014. Putting ancient winds and life into new sails: indigenous knowledge as a basis for education of sustainable development (ESD) - a case study of the return of marine biodiversity to Vanuau Navakavu, Fiji. Pages 163-184 in M. 'Otunuku, U. Nabobo-Baba, and S. JohanssonFua, editors. Of waves, winds and wonderful things: a decade of rethinking Pacific education. University of the South Pacific Press, Suva, Fiji.

Thaman, R. R., and W. C. Clarke. 1993. Agroforestry in the Pacific Islands: systems for sustainability. Pages 191-215 in W. C. Clarke and R. R. Thaman, editors. Agroforestry in the Pacific Islands: systems for sustainability. United Nations University Press, Tokyo, Japan.

Thaman, R., P. Lyver, R. Mpande, E. Perez, J. Cariño, and K. Takeuchi, editors. 2013. The contribution of indigenous and local knowledge systems to IPBES: building synergies with science. IPBES Expert Meeting Report. UNESCO, Paris, France.

Thaman, R. R., M. Meleisea, and J. Makasiale. 2002. Agricultural diversity and traditional knowledge as insurance against natural disasters. Pacific Health Dialog 9(1):76-85.

Thornton, T. F., and A. M. Scheer. 2012. Collaborative engagement of local and traditional knowledge and science in marine environments: a review. Ecology and Society 17(3): 8. http://dx.doi.org/10.5751/ES-04714-170308

Ticktin, T., A. N. Whitehead, and H. Fraiola. 2006. Traditional gathering of native hula plants in alien-invaded Hawaiian forests: 
adaptive practices, impacts on alien invasive species and conservation implications. Environmental Conservation 33 (3):185-194. http://dx.doi.org/10.1017/S0376892906003158

Timm, O., and H. F. Diaz. 2009. Synoptic-statistical approach to regional downscaling of IPCC twenty-first-century climate projections: seasonal rainfall over the Hawaiian Islands. Journal of Climate 22(16):4261-4280. http://dx.doi.org/10.1175/2009JCLI2833.1

Titcomb, M. 1972. Native use of fish in Hawaii. University of Hawai'i Press, Honolulu, Hawai'i, USA.

Trauernicht, C., B. P. Murphy, N. Tangalin, and D. M. J. S. Bowman. 2013. Cultural legacies, fire ecology, and environmental change in the Stone Country of Arnhem Land and Kakadu National Park, Australia. Ecology and Evolution 3(2):286-297. http://dx.doi.org/10.1002/ece3.460

Tscharntke, T., Y. Clough, S. A. Bhagwat, D. Buchori, H. Faust, D. Hertel, D. Hölscher, J. Juhrbandt, M. Kessler, I. Perfecto, C. Scherber, G. Schroth, E. Veldkamp, and T. C. Wanger. 2011. Multifunctional shade-tree management in tropical agroforestry landscapes - a review. Journal of Applied Ecology 48(3):619-629. http://dx.doi.org/10.1111/j.1365-2664.2010.01939.x

Turner, N. J., and F. Berkes. 2006. Coming to understanding: developing conservation through incremental learning in the Pacific Northwest. Human Ecology 34(4):495-513. http://dx.doi. org/10.1007/s10745-006-9042-0

Turner, N. J., and H. Clifton. 2009. "It's so different today": climate change and indigenous lifeways in British Columbia, Canada. Global Environmental Change 19(2):180-190. http://dx. doi.org/10.1016/j.gloenvcha.2009.01.005

Tuxill, J., and G. P. Nabhan. 2001. People, plants and protected areas: a guide to in situ management. Earthscan, London, UK.

UNFCCC [United Nations Framework Convention on Climate Change]. 2007. Climate change: impacts, vulnerabilities, and adaptation in developing countries. UNFCC, Bonn, Germany. [online] URL: http://unfccc.int/resource/docs/publications/impacts. pdf.

van Oudenhoven, F. J. W., D. Mijatović, and P. B. Eyzaguirre. 2011. Social-ecological indicators of resilience in agrarian and natural landscapes. Management of Environmental Quality: an International Journal 22(2):154-173. http://dx.doi. org/10.1108/14777831111113356

Vaughan, M. B., and P. M. Vitousek. 2013. Mahele: sustaining communities through small-scale inshore fishery catch and sharing networks. Pacific Science 67(3):329-344. http://dx.doi. org/10.2984/67.3.3

Vecchi, G. A., B. J. Soden, A. T. Wittenberg, I. M. Held, A. Leetmaa, and M. J. Harrison. 2006. Weakening of tropical Pacific atmospheric circulation due to anthropogenic forcing. Nature 441 (7089):73-76. http://dx.doi.org/10.1038/nature04744

Veitayaki, J. 1997. Traditional marine resource management practices used in the Pacific Islands: an agenda for change. Ocean and Coastal Management 37(1):123-136. http://dx.doi.org/10.1016/ $\underline{\mathrm{S} 0964-5691(96) 00069-5}$
Veitayaki, J. 1998. Traditional and community-based marine resources management system in Fiji: an evolving integrated process. Coastal Management 26(1):47-60. http://dx.doi. org/10.1080/08920759809362342

Vergara, N. T., and P. K. R. Nair. 1985. Agroforestry in the South Pacific region - an overview. Agroforestry Systems 3(4):363-379. http://dx.doi.org/10.1007/BF00055718

Vierros, M., A. Tawake, F. Hickey, A. Tiraa, and R. Noa. 2010. Traditional marine management areas of the Pacific in the context of national and international law and policy. United Nations University, Darwin, Australia. [online] URL: http://www.unutki. org/downloads/File/Publications/Traditional Marine Management_Areas_Sept_2010_webversion_v2_two_page_spread.pdf.

Vorsino, A. E., L. B. Fortini, F. A. Amidon, S. E. Miller, J. D. Jacobi, J. P. Price, S. 'O. Gon III, and G. A. Koob. 2014. Modeling Hawaiian ecosystem degradation due to invasive plants under current and future climates. PloS One 9(5): e95427. http://dx.doi. org/10.1371/journal.pone.0095427

Wagner, W. L., D. R. Herbst, and S. H. Sohmer. 1999. Manual of the flowering plants of Hawaiti. Revised edition, volume 1. University of Hawai'i Press, Honolulu, Hawai'i, USA.

Walker, B., C. S. Holling, S. R. Carpenter, and A. Kinzig. 2004. Resilience, adaptability and transformability in social-ecological systems. Ecology and Society 9(2): 5. [online] URL: http://www. ecologyandsociety.org/vol9/iss2/art5/.

Wilson, W. H. 1998. 1 ka'olelo Hawai' 1 ke ola, 'Life is found in the Hawaiian language'. International Journal of the Sociology of Language 132(1):123-138.

World Bank. 2012. Bilateral remittance matrix 2012. World Bank, Washington, D.C., USA. [online] URL: http://siteresources. worldbank.org/INTPROSPECTS/Resources/334934-1110315015165/ Bilateral Remittance Matrix 2012.xlsx. 